\title{
PENGARUH RANSUM YANG MENGANDUNG LIMBAH TAUGE FERMENTASI TERHADAP KECERNAAN SERAT KASAR, PROTEIN KASAR DAN ENERGI METABOLIS PADA ITIK LOKAL FASE STARTER
}

\author{
Effect of Diet Contains Bean Sprouts Fermented Against Crude Fiber Digestibility, Crude Protein \\ Digestibility and Energy Metabolic on Local Duck Starter Phase
}

\author{
Galuh Arum Pangestu, R. I. Pujaningsih, I. Mangisah \\ Faculty of Animal and Agricultural Science, Diponegoro University \\ Prof. H. Soedarto, SH, Tembalang, Semarang, Indonesia 50275 \\ E-mail: galuharumpangestu36@gmail.com
}

\begin{abstract}
This research aimed to reviewing level of bean sprout fermented used in duck diet against crude fiber digestibility, crude protein digestibility and metabolic energy of diet. The research was proccessed using Complete Random Design (CRD) with four treatments and four replications. The parameters observed were crude fiber digestibility, crude protein digestibility and metabolic energy. The research material used was 48 male ducks with starter phase, treatment diet, flock cage, battery cage, feed tray, water tube, $\mathrm{HCl}$, plasctic tray, scales, hygrometer, a set of proximate and gross energy analysis equipment. The research method consits two stages, the first stage was fermented of bean sprouts using $6 \%$ of Trichoderma harzianum for six days. The second phase was in vivo method with addition of bean sprout fermented in diet respectively $T_{0} 0 \%, T_{1} 5 \%, T_{2} 10 \%$ and $T_{3} 15 \%$. The result data was tested by $F$ test based on analysis of varians and if there was significant effect of treatment $(P<0.05)$ followed by the test of least significance defferent $(L S D)$. The result of effect of diet containing bean sprouts fermented were no affected $(P>0.05)$ the crude fiber digestibility, crude protein digestibility and metabolic energy for starter phase of local ducks.
\end{abstract}

Keywords : Bean Sprouts, Digestibility, Duck, Fermentation, Tricodherma harzianum.

\section{PENDAHULUAN}

Pemanfaatan limbah merupakan salah satu solusi yang dapat dilakukan untuk mengurangi biaya pakan dengan tetap memperhatikan kandungan nutrisi dan juga ketersediaan dari limbah tersebut bila dijadikan sebagai pakan ternak. Limbah tauge merupakan salah satu limbah yang dapat digunakan sebagai pakan alternatif untuk ternak. Ketersediaan limbah tauge cukup melimpah $1 \mathrm{~kg}$ kacang hijau yang dikecambahkan menghasilkan $2,98 \mathrm{~kg}$ tauge dan 112,98 gram atau $0,11 \%$ nya merupakan limbah kepala tauge (Darmiwati dan Muslim, 2012). Potensi limbah tauge di Kota Bogor berkisar antara 951 - $1426 \mathrm{~kg} / \mathrm{hari}$ (Rahayu et al., 2010). Kandungan nutrisi limbah tauge cukup baik yang terdiri dari protein kasar sebanyak 12,09\%, serat kasar 50,89\%, kadar air $32,4 \%$, lemak kasar 1,18\%, kalsium 0,37\%, phosfor $0,33 \%$ dan energi sebanyak 2689 $\mathrm{Kkal} / \mathrm{kg}$.

Kandungan serat kasar limbah tauge yang cukup tinggi yaitu 50,89\% dengan kadar selulosa mencapai $45,1 \%$ menjadi faktor pembatas limbah tauge untuk dijadikan pakan unggas. Salah satu pengolahan yang dapat dilakukan yaitu proses fermentasi menggunakan Trichoderma harzianum. Fermentasi merupakan proses yang melibatkan aktivitas mikroba berlangsung secara anaerob dengan menggunakan substrat tertentu dan menghasilkan suatu produk bernilai lebih tinggi (Mirwandhono et al., 2006). Trichoderma harzianum menghasilkan enzim yang mampu merombak selulosa dan hemiselulosa sehingga akan menurunkan kadar serat kasar dan meningkatkan protein kasar. Salah satu ternak dengan kemampuan mencerna serat kasar yang lebih baik yaitu ternak itik. Ternak itik memiliki kemampuan mencerna serat kasar yang lebih baik dari pada ternak unggas lain sampai taraf $\pm 10 \%$. Kandungan serat kasar dalam ransum akan berpengaruh terhadap kecernaan protein dan bahan organik lain selain itu kecernaan merupakan salah satu faktor yang mempengaruhi energi metabolis bahan pakan. 
Berdasarkan latar belakang tersebut, perlu dilakukan penelitian mengenai penggunaan limbah tauge fermentasi dalam ransum itik terhadap kecernaan serat kasar, protein kasar dan energi metabolis. Tujuan penelitian adalah untuk mengkaji level penggunaan limbah tauge fermentasi dalam ransum itik terhadap kecernaan serat kasar, kecernaan protein kasar dan energi metabolis ransum. Hipotesis penelitian ini yaitu penggunaan level limbah tauge fermentasi dalam ransum itik lokal fase starter meningkatkan kecernaan serat kasar, kecernaan protein kasar dan energi metabolis ransum.

\section{MATERI DAN METODE}

Penelitian dilaksanakan di kandang percobaan Desa Kuripan, Kecamatan Purwodadi Kabupaten Grobogan serta di Laboratorium Teknologi Pakan dan Ilmu Nutrisi Pakan Fakultas Peternakan dan Pertanian Universitas Diponegoro, Semarang pada bulan November 2016 - Februari 2017.

\section{Materi}

Materi yang digunakan dalam penelitian ini adalah ternak itik tegal jantan dengan umur 7 hari sebanyak 48 ekor. Ransum perlakuan dapat dilihat pada Tabel 1. dengan kandungan nutrisi terdiri dari PK $18 \%$, SK $12-13 \%$, Ca $0,90 \%$, P $0,70 \%$ dan EM $2800 \mathrm{Kkal} / \mathrm{kg}$. Kandang yang terdiri dari kandang flok terbuat dari bambu dan alas semen cor dengan ukuran panjang $80 \mathrm{~cm}$ lebar $80 \mathrm{~cm}$ dan tinggi $50 \mathrm{~cm}$ serta kandang baterai yang terbuat dari besi dengan panjang 40 $\mathrm{cm}$ lebar $30 \mathrm{~cm}$ dan tinggi $40 \mathrm{~cm}$. Peralatan total koleksi yang terdiri dari nampan plastik, tempat pakan, tempat minum sebanyak 32 buah dan sprayer 1 buah. Seperangkat peralatan analisis proksimat dan gross energi. Bahan yang digunakan terdiri dari Trichoderma harzianum, molases, aquades dan $\mathrm{HCl}$.

\section{Metode}

Penelitian terdiri dari dua tahap yaitu tahap persiapan dan tahap pelaksanaan. Penelitian tahap persiapan meliputi proses fermentasi, yang diawali dengan limbah tauge dikumpulkan sebanyak $22 \mathrm{~kg}$. Limbah tauge ditimbang, kebutuhnan air dihitung agar bahan yang difermentasi mengandung 60-70\% air. Kemudian Trichoderma harzianum dilarutkan dengan air sebanyak 6\% dari bahan kering, dalam larutan Trichoderma harzianum ditambahkan molases sebanyak 5\% dari bahan kering kemudian dicampur dengan limbah tauge dan diaduk hingga homogen. Setelah homogen dimasukkan kedalam plastik yang telah dilubangi, diperam selama 6 hari. Setelah 6 hari, kemudian diangin-anginkan untuk menghentikan proses fermentasi. Kemudian bahan pakan yang telah tersedia disusun sesuai dengan formulasi yang telah dihitung sebelumnya.

Penelitian tahap pelaksanaan meliputi perlakuan pakan ransum yang mengandung limbah tauge fermentasi terhadap ternak kemudian total koleksi untuk pengukuran kecernaan. Penimbangan bobot badan dilakukan saat itik datang dan setiap seminggu sekali selama pemeliharan.

Tabel 1. Komposisi dan Kandungan Nutrisi Ransum Perlakuan

\begin{tabular}{lrrrr}
\hline \hline \multicolumn{1}{c}{ Bahan Pakan } & \multicolumn{1}{c}{ T0 } & T1 & T3 \\
\hline Jagung & 26,7 & 27,6 & 28,3 & 29 \\
Bungkil kedelai & 18,7 & 18,6 & 18,8 & 18,9 \\
Bekatul & 18,9 & 18,8 & 18,2 & 18,3 \\
Pollard & 12,9 & 12,6 & 12,3 & 11,7 \\
Tepung ikan & 6,8 & 6,8 & 6,4 & 6,1 \\
Limbah tauge & 15 & 10 & 5 & - \\
Limbah tauge fermentasi & - & 5 & 10 & 15 \\
Premix & 1 & 1 & 1 & 1 \\
\hline Total & 100 & 100 & 100 & 100 \\
\hline EM & 2843,73 & 2839,39 & 2836 & 2832,87 \\
PK & 18,30 & 18,31 & 18,32 & 18,31 \\
SK & 13,02 & 12,76 & 12,44 & 12,21 \\
LK & 4,23 & 4,22 & 4,15 & 4,14 \\
Ca & 0,98 & 0,98 & 0,93 & 0,90 \\
P & 0,76 & 0,76 & 0,75 & 0,74 \\
\hline Keter
\end{tabular}

Keterangan : Hasil Analisis Proksimat Laboratorium Ilmu Nutrisi dan Pakan, Fakultas Peternakan dan Pertanian, Universitas Diponegoro, 2016. 
Pemberian pakan dilakukan 2 kali sehari pukul 06.00 WIB sebanyak $60 \%$ dan pukul 16.00 WIB sebanyak 40\%, sebelum pakan diberikan terlebih dahulu ditimbang apabila terdapat sisa juga akan ditimbang, air minum diberikan secara ad libitum. Pemeliharaan dilakukan selama 28 hari, proses adaptasi dilakukan selama 7 hari, pemberian perlakuan selama 16 hari dan total koleksi dilakukan selama 5 hari. Pengambilan data dilakukan pada 5 hari terakhir dengan metode total koleksi. Kandang baterai disiapkan, bobot badan 16 ekor itik yang akan ditampung ekskretanya ditimbang terlebih dahulu, hari pertama total koleksi itik dipuasakan selama 24 jam namun tetap diberi air minum dan ekskretanya belum ditampung. Setelah pemuasaan selama 24 jam ternak kembali diberi pakan dan mulai ditampung ekskretanya.

Hari terakhir penampungan ternak kembali dipuasakan dan hanya diberi minum, untuk memperoleh data endogenus sebanyak 2 ekor ternak itik dipuasakan pada hari pertama dan ekskreta tidak ditampung, untuk hari kedua dan ketiga baru ekskreta ditampung dengan kondisi ternak tetap dipuasakan. Ekskreta yang ditampung disemprot dengan $\mathrm{HCl}$ setiap 2 jam sekali, setelah 24 jam berat basah ekskreta ditimbang, ekskreta dijemur, setelah kering kemudian ekskreta ditimbang kembali, ekskreta dihaluskan dan dianalisis kemudian kecernaan dihitung dengan menggunakan rumus.

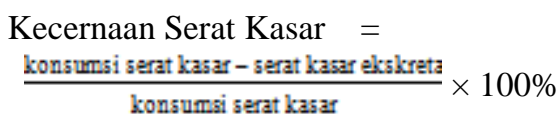

Kecernaan Protein Kasar $=$ $\frac{\text { konsursi protain lasar-protein lasar elkskreta }}{\text { kronsurnsiprotein lasar }} \times 100 \%$

Energi metabolis murni $=$ $\frac{\text { Konsumsi GE-(jumlah GE - jumlah GE endogenus:) }}{\text { Konsursirangum }}$. 1000

\section{HASIL DAN PEMBAHASAN}

\section{Kecernaan Serat Kasar}

Ransum perlakuan mengandung limbah tauge baik difermentasi atau tidak $\mathrm{T}_{0}, \mathrm{~T}_{1}, \mathrm{~T}_{2}$ dan $\mathrm{T}_{3}$ tidak berpengaruh nyata $(\mathrm{P}>0,05)$ terhadap kecernaan serat kasar dapat dilihat pada Tabel 2. Walaupun secara analisis statistik data kecernaan serat kasar tidak terdapat pengaruh nyata $(\mathrm{P}>0,05)$ namun secara numerik data kecernaan serat kasar mengalami kenaikan sesuai dengan perlakuan $\mathrm{T}_{0}, \mathrm{~T}_{1}, \mathrm{~T}_{2}$ dan $\mathrm{T}_{3}$ masing-masing yaitu 23,05\%, 23,14\%, 25,61\% dan $29,40 \%$. Kenaikan kecernaan serat kasar disebabkan oleh kandungan serat kasar berupa selulosa dalam ransum perlakuan $T_{0}, T_{1}, T_{2}$ dan $\mathrm{T}_{3}$ yang semakin sedikit seiring dengan penggunaan limbah tauge fermentasi dalam ransum perlakuan yang semakin banyak, dengan berkurangnya kandungan selulosa dalam ransum kecernaan serat kasar semakin meningkat tetapi belum signifikan.

Kecernaan serat kasar ransum perlakuan tidak terdapat pengaruh nyata karena kandungan serat kasar dan konsumsi serat kasar ransum perlakuan relatif sama. Kandungan serat kasar dalam ransum, komposisi penyusun serat kasar dan aktivitas dari mikroorganisme mempengaruhi kecernaan serat kasar. Hal ini sesuai pendapat Hidanah et al. (2013) kecernaan serat kasar dipengaruhi oleh beberapa faktor antara lain konsumsi pakan, kadar serat dalam pakan, komposisi penyusun serat kasar dan aktivitas mikroorganisme. Menurut Prawitasari et al. (2012) menyatakan bahwa kandungan serat kasar dalam ransum yang semakin tinggi menyebabkan kecernaan serat kasar yang semakin rendah begitu juga sebaliknya.

Kandungan serat kasar dalam ransum yang diberikan berpengaruh terhadap konsumsi pakan karena serat kasar bersifat bulky (pengganjal). Hal ini sesuai pendapat Wahju (2004) serat kasar memiliki sifat bulky (pengganjal) terdiri dari selulosa, hemiselulosa dan lignin dimana sebagian besar sulit dicerna oleh unggas.

Tabel 2. Rataan Kecernaan Serat Kasar Ransum yang Mengandung Limbah Tauge pada Itik Lokal Fase Starter

\begin{tabular}{|c|c|c|c|c|}
\hline \multirow[t]{2}{*}{ Ulangan } & \multicolumn{4}{|c|}{ Kecernaan Serat Kasar } \\
\hline & $\mathrm{T}_{\mathrm{o}}$ & $\mathrm{T}_{1}$ & $\mathrm{~T}_{2}$ & $\mathrm{~T}_{3}$ \\
\hline & & & .............. & ............ \\
\hline 1 & 25,85 & 22,92 & 28,48 & 34,66 \\
\hline 2 & 20,55 & 28,06 & 46,12 & 38,62 \\
\hline 3 & 23,02 & 14,31 & 16,15 & 23,18 \\
\hline 4 & 22,78 & 27,35 & 11,70 & 21,12 \\
\hline Rerata & 23,05 & 23,16 & 25,61 & 29,40 \\
\hline
\end{tabular}


Tingkat konsumsi pakan menentukan kandungan serat kasar yang dikonsumsi dimana kandungan serat kasar dalam ransum juga menentukan banyak sedikitnya serat kasar yang dicerna oleh itik. Konsumsi pakan menunjukkan hasil yang relatif sama sehingga konsumsi serat kasar yang dihasilkan juga relatif sama, hal ini menyebabkan tidak terdapat pengaruh nyata $(\mathrm{P}>0,05)$ terhadap kecernaan serat kasar.

Kandungan serat kasar limbah tauge fermentasi mengalami penurunan namun ransum perlakuan yang mengandung limbah tauge fermentasi tidak berpengaruh nyata $(\mathrm{P}>0,05)$ terhadap kecernaan serat kasar. Fermentasi limbah tauge menggunakan Trichoderma harzianum sebanyak $6 \%$ dengan lama pemeraman 6 hari mampu menurunkan kandungan serat kasar limbah tauge sebanyak $8,90 \%$ yang semula $50,89 \%$ menjadi $46,36 \%$. Kandungan serat kasar limbah tauge fermentasi lebih rendah dari limbah tauge yang tidak difermentasi karena fermentasi merupakan suatu proses yang menghasilkan produk baru yang terjadi secara aerob ataupun anaerob dengan melibatkan mikroba atau substratnya secara terkontrol. Hasil kecernaan serat kasar pada penelitian sama karena kandungan serat kasar berupa selulosa yang sulit dicerna. Pencernaan serat kasar pada unggas terjadi disekum dengan bantuan mikroorganisme karena unggas tidak memiliki selulase. Hal ini sesuai pendapat Wahju (2004) unggas tidak memiliki enzim selulase yang dapat memecah komponen serat kasar berupa selulosa.

\section{Kecernaan Protein Kasar}

Kandungan protein kasar limbah tauge fermentasi mengalami kenaikan sekitar 11,23\% yang semula $12,09 \%$ menjadi $13,62 \%$ hal ini dikarenakan selama proses fermentasi jumlah koloni mikroba yang semakin meningkat dimana koloni tersebut merupakan protein sel tunggal secara tidak langsung akan meningkatkan kandungan protein kasar substrat. Ransum perlakuan yang mengandung limbah tauge baik difermentasi atau tidak dalam ransum tidak berpengaruh nyata $(\mathrm{P}>0,05)$ terhadap kecernaan protein kasar dapat dilihat pada Tabel 3 karena komponen serat kasar berupa selulosa dalam limbah tauge yang sulit untuk dicerna. Kandungan serat kasar berupa selulosa dalam ransum perlakuan $T_{0}, T_{1}, T_{2}$ dan $T_{3}$ memang semakin sedikit seiring dengan penggunaan limbah tauge fermentasi dalam ransum perlakuan yang semakin banyak namun masih terlalu tinggi untuk ransum itik. Komponen serat kasar berupa selulosa yang sulit dicerna menyebabkan kandungan nutrisi lain yang seharusnya dapat dicerna tetapi berikatan dengan selulosa kemudian terbuang bersama ekskreta. Hal ini sesuai pendapat Mangisah et al. (2009) semakin rendah kecernaan serat kasar akan menyebabkan kecernaan dari zat nutrisi lain juga akan rendah karena zat nutrisi yang seharusnya dapat tercerna ikut terbuang bersama ekskreta, serta kasar dapat menghambat kerja dari enzim pencernaan.

Kandungan protein kasar dan konsumsi protein dalam ransum yang relatif sama mempengaruhi kecernaan protein kasar. Tingkat konsumsi pakan yang sama menyebabkan tingkat konsumsi protein kasar yang relatif sama sehingga kecernaan protein kasar juga relatif sama sehingga tidak terdapat pengaruh nyata $(\mathrm{P}>0,05)$ terhadap kecernaan protein kasar. Semakin sedikit jumlah protein kasar yang terbuang bersama ekskreta maka kecernaan protein kasar akan semakin tinggi. Hal ini sesuai pendapat Winedar et al. (2006) banyaknya protein kasar yang dikonsumsi akan mempengaruhi kecernaan protein kasar. Faktor pengaruh kecernaan protein kasar terdiri dari kandungan protein di dalam ransum, banyaknya protein yang masuk dalam saluran pencernaan, suhu lingkungan dan kondisi fisiologis ternak. Menurut Prawitasari et al. (2012) semakin rendah kandungan protein kasar dalam ransum maka kecernaannya juga akan semakin rendah dan begitu juga sebaliknya.

Tabel 3. Rataan Kecernaan Protein Kasar Ransum yang Mengandung Limbah Tauge pada Itik Lokal Fase Starter

\begin{tabular}{|c|c|c|c|c|}
\hline \multirow[t]{2}{*}{ Ulangan } & \multicolumn{4}{|c|}{ Kecernaan Protein Kasar } \\
\hline & $\mathrm{T}_{\mathrm{o}}$ & $\mathrm{T}_{1}$ & $\mathrm{~T}_{2}$ & $\mathrm{~T}_{3}$ \\
\hline & & & & \\
\hline 1 & 73,26 & 75,36 & 73,63 & 77,60 \\
\hline 2 & 73,50 & 74,70 & 77,85 & 77,33 \\
\hline 3 & 71,34 & 71,32 & 67,32 & 74,11 \\
\hline 4 & 73,30 & 73,21 & 71,06 & 69,93 \\
\hline Rerata & 72,85 & 73,65 & 72,46 & 74,74 \\
\hline
\end{tabular}


Tabel 4. Rataan Energi Metabolis Murni Ransum yang Mengandung Limbah Tauge pada Itik Lokal Fase Starter

\begin{tabular}{|c|c|c|c|c|}
\hline \multirow[t]{2}{*}{ Ulangan } & \multicolumn{4}{|c|}{ Perlakuan } \\
\hline & $T_{0}$ & $\mathrm{~T}_{1}$ & $\mathrm{~T}_{2}$ & $\mathrm{~T}_{3}$ \\
\hline & \multicolumn{4}{|c|}{...kkal/ kg.. } \\
\hline 1 & 2634,57 & 2550,36 & 2594,40 & 2541,86 \\
\hline 2 & 2582,45 & 2466,43 & 2340,55 & 2390,22 \\
\hline 3 & 2415,56 & 2577,38 & 2159,01 & 2246,24 \\
\hline 4 & 2496,56 & 2498,40 & 2530,00 & 2381,48 \\
\hline Rerata & 2580,30 & 2444,91 & 2349,55 & 2476,61 \\
\hline
\end{tabular}

Kecernaan protein yang diperoleh berkisar antara 69,36-71,94\%, termasuk dalam kecernaan protein sedang. Hal ini sesuai pendapat Abun, Saefulhadjar, and Haetami (1995) kecernaan protein kasar terbagi menjadi 3 yaitu tingkat kecernaan rendah berkisar antara $50-60 \%$, tingkat kecernaan sedang berkisar antara 60-70\% dan kecernaan tinggi lebih dari $70 \%$. Konsumsi protein harus sesuai dengan kebutuhan itik agar dapat dimanfaatkan dengan baik dan tidak terbuang percuma bersama ekskreta. Protein kasar berfungsi untuk kebutuhan hidup pokok, pertumbuhan dan produksi. Menurut Prawitasari et al. (2012) protein kasar akan dimanfaatkan ternak untuk kebutuhan hidup pokok, pertumbuhan dan produksi.

\section{Energi Metabolis Murni}

Analisis ragam menunjukkan hasil bahwa penggunaan limbah tauge baik difermentasi atau tidak dalam ransum itik tidak berpengaruh nyata $(\mathrm{P}>0,05)$ terhadap nilai energi metabolis murni dapat dilihat pada Tabel 4. Hal ini dapat dipengaruhi oleh kecernaan nutrien ransum yang tidak berbeda nyata. Kandungan selulosa yang masih terlalu tinggi pada ransum perlakuan sulit untuk dicerna menyebabkan kecernaan serat kasar tidak berbeda nyata. Kecernaan serat kasar yang tidak berbeda nyata menyebabkan kecernaan protein kasar dan bahan organik juga tidak berbeda nyata karena zat nutrisi lain yang seharusnya dapat tercerna berikatan dengan selulosa kemudian ikut terbuang bersama ekskreta. Hal ini sesuai pendapat Bahri dan Rusdi (2008) kandungan serat kasar yang tinggi akan menurunkan kecernaan bahan pakan penyerapan zat-zat makanan akan menurun sehingga kandungan energi metabolis juga akan menurun. Menurut Wulandari et al. (2013) ketersediaan energi metabolis dalam ransum akan berkurang apabila kandungan polisakarida dalam serat kasar susah untuk dicerna begitu juga sebaliknya

Faktor lain yang mempengaruhi nilai energi metabolis murni tidak berbeda nyata yaitu kandungan energi ransum perlakuan dan konsumsi energi yang relatif sama. Tingkat konsumsi pakan yang sama menyebabkan tingkat konsumsi energi yang relatif sama, energi metabolis murni juga relatif sama sehingga tidak terdapat pengaruh nyata $(\mathrm{P}>0,05)$ terhadap energi metabolis murni. Menurut Hapsari (2006) faktor yang mempengaruhi energi metabolis terdiri dari kandungan energi ransum, konsumsi pakan, jenis ternak dan umur serta kemampuan ternak untuk melakukan metabolisme didalam tubuh. Bahri dan Rusdi (2008) menyatakan bahwa energi metabolis merupakan energi yang digunakan ternak untuk menjalankan aktivitas berupa mempertahankan suhu tubuh, metabolisme, aktifitas fisik, produksi, reproduksi dan pembentukan jaringan.

\section{SIMPULAN}

Simpulan penelitian ini yaitu penggunaan limbah tauge yang difermentasi menggunakan Trichoderma harzianum dalam ransum itik lokal fase starter tidak meningkatkan kecernaan serat kasar, protein kasar dan energi metabolis.

\section{DAFTAR PUSTAKA}

Abun, Saefulhadjar, D., \& Haetami, K. (1995). Nilai Energi Metabolis dan Kecernaan Ransum Mengandung Imbuhan Pakan Berbasis Ekstrak Limbah Udang pada Ayam Broiler ( Metabolizable Energy and Digestibility Value of Ration Containing Feed Supplement Based on Waste Extract Shrimp on Broilers ), 1-6.

Abun, D. Saefulhadjar dan K. Haetami. 2012. Nilai energi metabolis dan kecernaan ransum mengandung imbuhan pakan berbasis ekstrak limbah udang pada ayam broiler. J. Ilmu Ternak. 12 (1) : 1 6.

Bahri, S dan Rusdi. 2008. Evaluasi energi metabolis pakan lokal pada ayam petelur. J. Agroland. 15 (1) : 75-78. 
Darmiwati dan Muslim. 2012. Studi potensi dan kandungan nutrisi limbah kepala tauge sebagai pakan ternak alternatif di Kabupaten Kuantan Singingi. Jurnal Ilmiah Peternakan. 1 (1) : 1-7.

Hapsari, R. P. 2006. Energi metabolis dan Efisiensi Penggunaan Energi Ransum Ayam Broiler yang Mengandung Limbah Restoran sebagai Pengganti Dedak Padi. Fakultas Peternakan, Institut Pertanian Bogor, Bogor. (Skripsi).

Hidanah, S., E. M. Tamrin., D. S. Nazar dan E. Safitri. 2013. Limbah tempe dan limbah tempe fermentasi sebagai substitusi jagung terhadap daya cerna serat kasar dan bahan organik pada itik petelur. Jurnal Agroveteriner. 2 (1) : 71-79.

Mangisah, I., B. Sukamto dan M. H. Nasution. 2009. Implementasi daun eceng gondok fermentasi dalam ransum itik. J. Indon. Trop. Anim. Agric. 34 (2) : 127-133.

Mirwandhono, E., I. Bachari dan D. Situmorang. 2006. Uji nilai nutrisi kulit ubi kayu yang difermentasi dengan Aspergillus niger (nutrient value test of cassava tuber skin fermented by Aspergillus niger). Jurnal Agribisnis Peternakan. 2 (3) : 91 - 95.

Prawitasari, R. H., V. D. Y. B. Ismdi dan I. Estiningdriati. 2012. Kecernaan protein kasar dan serat kasar serta laju digesta pada ayam arab yang diberi ransum dengan berbagai level Azolla microphylla. Animal Agricultur Journal. 1 (1) : 471- 478.

Rahayu, S., D. Diapari., D. S. Wandito dan W. W. Ifafah. 2010. Survei potensi ketersediaan limbah tauge sebagai pakan ternak alternatif di kotamadya Bogor. Laporan Penelitian. Fakultas Peternakan. Institut Pertanian Bogor, Bogor.

Wahju, J. 2004. Ilmu Nutrisi Unggas. Cetakan ke lima. Gadjah Mada University Press, Yogyakarta.

Winedar, H., S. Listyawati dan Sutarno. 2006. Daya cerna protein pakan, kandungan protein daging, dan pertambahan berat badan ayam broiler setelah pemberian pakan yang difermentasi dengan Effective Microorganisms-4 (EM-4). J. Bioteknologi. 3 (1) : 14 -19.

Wulandari, K. Y, V. D. Y. B. Ismadi., dan Tristiarti. 2013. Kecernaan serat kasar dan energi metabolis pada ayam Kedu umur 24 minggu yang diberi ransum dengan berbagai level protein kasar dan serat kasar. Journal Animal Agriculture. 2 (1) : 9 - 17 . 